Nadir Görülen Odontojenik Enfeksiyon Yayılımı: Temporal Fossa Apsesi

\title{
An Unusual Spread of Odontogenic Infection: Temporal Fossa Abscess
}

Alper Dilci, Mustafa Acar

1 Eskişehir Yunus Emre Devlet Hastanesi, Kulak Burun Boğaz Hastalıkları Bölümü, Eskişehir, Türkiye

\section{$\ddot{O} Z$}

Derin boyun enfeksiyonlarının en sik nedenleri odontojenik kaynaklı olmakla beraber odontojenik enfeksiyonlar nadiren de olsa temporal fossayı etkilemektedir. Temporal fossa enfeksiyonlarl, süperfisyel ve derin temporal bölgeyi içeren ve bu alanların inflamasyon ve ödemiyle karakterize bir klinik tablodur. Temporal fossa enfeksiyonları; başlıca kafa travması, maksiller sinüzit, saç ve saçlı deri kaynakl, otolojik kaynaklı olmak üzere nadiren de olsa odontojenik kaynaklı da olabilmektedir. Bu olgu sunumunda odontojenik bir odaktan kaynaklanan temporal fossa apsesi paylaşılmıştır. Bu olgu sunumunun amacl; temporal fossa apsesi ile başvuran ve odontojenik kaynakl enfeksiyon tespit edilen hastanin tanı ve tedavi planını paylaşmaktır.

Anahtar Kelimeler: temporal fossa, apse, derin boyun enfeksiyonu, odontojenik

\begin{abstract}
The most common causes of deep neck infections are odontogenic, but odontogenic infections rarely affect the temporal fossa. Temporal fossa infection is a clinical picture characterized by inflammation and edema of superficial and deep temporal region. Temporal fossa infections arise mainly because of head trauma, maxillary sinusitis, infections of hair and scalp, otologic causes and rarely odontogenic origin. In this case, a patient with temporal fossa abscess originated from odontogenic infection was shared. The purpose of this case presentation is; to share the diagnosis and management of the patient who presented with temporal fossa infection arised from odontogenic origin.
\end{abstract}

Key words: temporal fossa, abscess, deep neck infection, odontogenic

Iletişim / Correspondence:

Dr. Alper Dilci

Eskişsehir Yunus Emre Devlet Hastanesi, Kulak Burun Boğaz Hastalıkları Bölümü, Eskişehir, Türkiye

E-mail:alperdilci@yahoo.com

Başvuru Tarihi: 11.04.2018

Kabul Tarihi: 06.12.2018 


\section{INTRODUCTION}

Superficial and deep neck infections are still observed despite early admission of patients, early diagnosis and treatment and common usage of broad spectrum antibiotics in clinical practice. The identification of the potential microbial agents and the anatomical gaps in the head and neck region, the fascia planes, and the relationship of these anatomical structures are the most important points in the management of neck infections (1). Most common cause of deep neck infections are odontogenic in adults and upper respiratory tract infections in children (2). Deep neck infections are usually seen in anatomical spaces of the neck like parapharyngeal or retropharyngeal space, but rarely seen in the cranial regions such as the temporal fossa.

Temporal fossa infections are a clinical condition characterized by the inflammation of the superficial and deep region of temporal space. Superficial temporal fossa extends superiorly to the pericranium, lateral to the temporalis muscle, and medial to the temporoparietal fascia; and deep temporal fossa is located between temporal fascia and temporal bone (3). Temporal fossa infections arise commonly from head trauma, hair and scalpinduced causes, and otological reasons, as well as odontogenic origin (4). Temporal fossa infections and abscess can be complicated by osteomyelitis, mediastinitis and meningitis if the disease is not treated properly (5). Temporal fossa abscess are located superior to zygomatic arch and posterior to the lateral orbital rim. According to its size, the abscess may extends to the masseter region or crosses temporal bone and extends to the parietal, frontal, and occipital bone (6). The treatment of temporal fossa abscess consists of drainage of abscess and treatment of odontogenic source with wide spectrum of appropriate antibiotherapy. In this case report; the diagnosis and treatment plan of the patient with a large temporal fossa abscess originating from odontogenic origin is shared.

\section{CASE REPORT}

A 42-year-old female patient was admitted to the Department of ENT of Eskişehir Yunus Emre State Hospital with complaints of pain in the left temporal region, trismus, fever and malaise. She had dental problems but did not care and had no treatment then her complaints were increased over the past week. On physical examination; approximately $9-10 \mathrm{~cm}$ sized abscess was found in the parietal and frontal region filling the entire temporal fossa in the left temporal region. Trismus was present, oral hygiene was bad, there was infected tooth decay in upper left molar tooth. The general condition of the patient was serious, sluggish and fever of $38.7^{\circ} \mathrm{C}$. Elevated WBC level with $14.610^{\prime} 3$ / uL, elevated sedimentation rate with $30 \mathrm{~mm} / \mathrm{hr}$ and elevated CRP level with 27.4 $\mathrm{mg} / \mathrm{L}$ were found in the laboratory study. The patient was hospitalized and surgical abscess drainage and parenteral antibiotic treatment were planned.

The patient was empirically treated with parenteral sulbactam ampicillin (3 g IV every 6 hours) and clindamycin ( $600 \mathrm{mg}$ IV every 6 hours ) antibiotherapy and paracetamol with antipyretic and anti-inflammatory treatment and surgical preparation planned. There was an abscess with a size of approximately $95 * 20 \mathrm{~mm}$ extending from the base of the left temporal region to the level of the parietal central semi- ovale, extending to the left ventricular region and having a size of about $25 *$ $15 \mathrm{~mm}$ at this distance on contrast-enhanced CT in the radiological examination ( Figure 1).

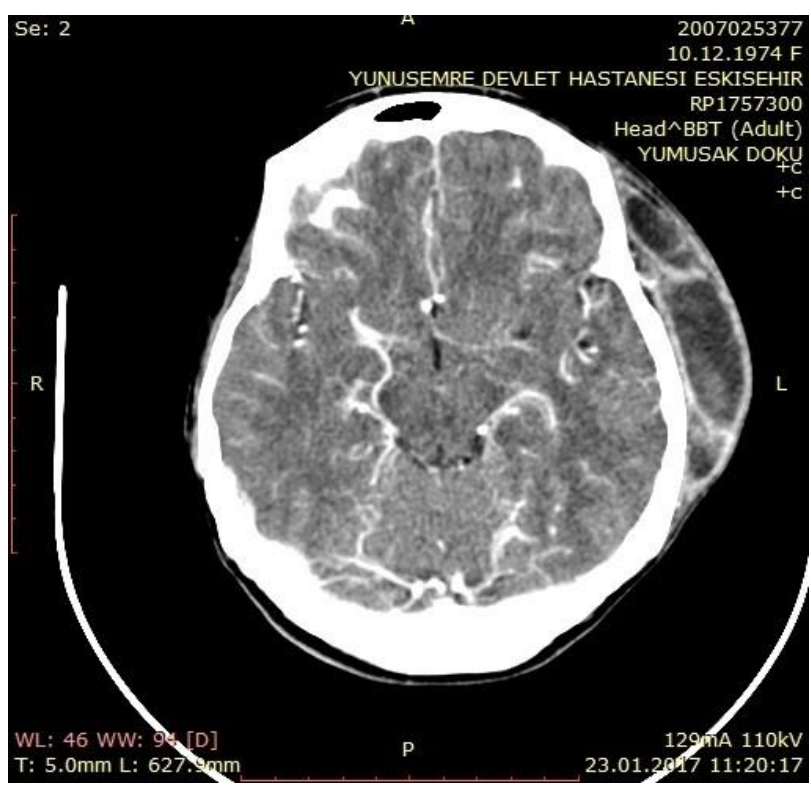

Figure 1. Contrast enhanced CT image of temporal fossa abscess in pre-treatment period

Abscess drainage was performed minimal invasively with a $1 \mathrm{~cm}$ incision from the scalp ( Figure 2). 


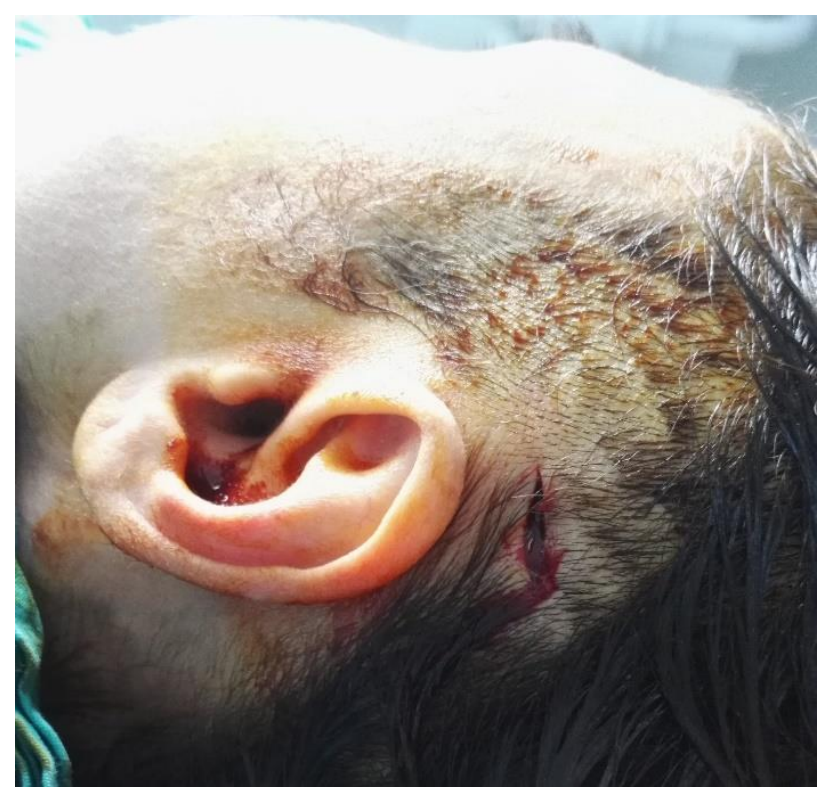

Figure 2. Incision of abscess drainge procedure in minimal invasive fashion

The cavity was thoroughly cleaned, washed and drained. Enterococcus faecalis was present in the abscess culture and piperacillin was replaced with tazobactam sodium in the antibiotherapy regimen. Drain was removed the next day and antibiotherapy was completed in 10 days. WBC level was reduced to $7.4310^{\prime} 3$ / uL, and the sedimentation values normalized with CRP and status of patient was improved. The abscess was completely resolved, and there was some inflammation only in the temporalis muscle and in the masticator muscles in the control CT (Fig 3).

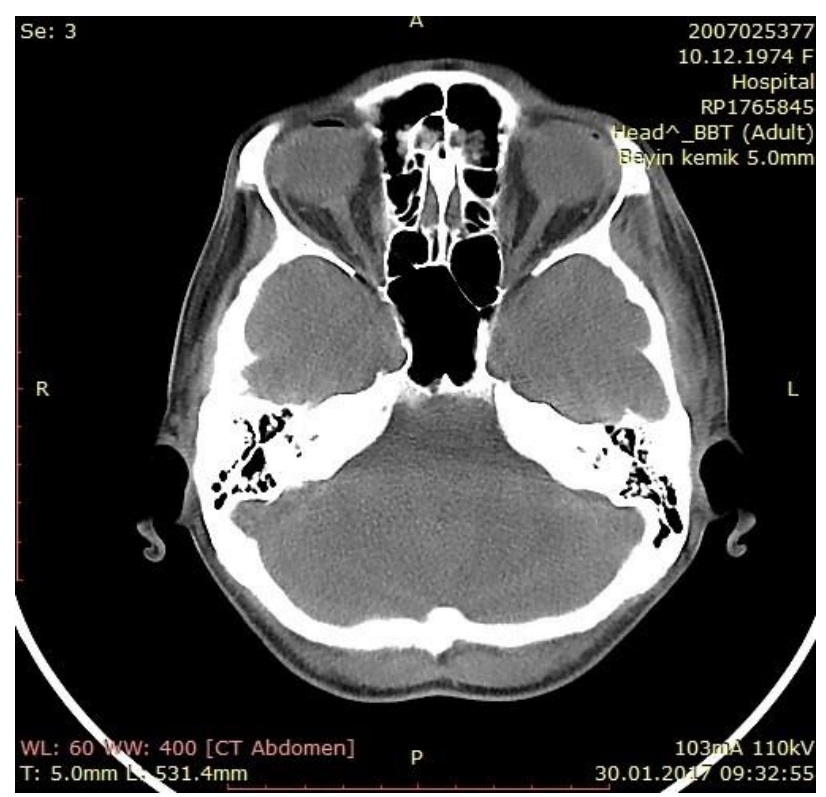

Figure 3. Contrast enhanced CT image of temporal fossa abscess in post-treatment period
The patient's complaints improved, the trismus passed after treatment and patient was discharged with no sequele. The patient was directed to the dentist for the treatment of the odontogenic infection source.

\section{DISCUSSION}

Odontogenic infections can be associated with many complications in the head and neck area, and it forms the majority of maxillofacial infections (7). Temporal fossa infections and abscess; usually caused by maxillary sinusitis, maxillary sinus fractures, temporomandibular arthroscopy, injections, otological and scalp-induced causes. Infections involving the temporal region and temporal abscess have been reported after tooth extraction, odontogenic infections $(3,8)$.

When the dental-induced temporal fossa infections are examined in the literature, they are seen in an average age of 40 years. In most cases, temporal fossa abscess was seen after maxillary molar teeth infection or extraction and almost all cases required surgical approach (3). Our case is consistent with the literature both in terms of age and treatment approach. Pain, fever, swelling, weakness, decreased mouth openness due to myofasciitis, swallowing impairment could be seen in temporal fossa infections, and all of these clinical symptoms were present in our case.

The diagnosis of temporal fossa abscess is easily established by history, physical examination and simple laboratory examinations. CT examination is useful and necessary for the detection of the airway condition in a possible respiratory complication or emergency surgical plan (9). Quick and easy applicability and the ability to examine detailed anatomical details are other benefits of CT.

If the temporal fossa abscess is not diagnosed and treated quickly and appropriately, it may progress and show many complications. The anatomical relations should be kept in mind when creating a treatment plan due to the proximity of the masseteric and the zygomatic region and the infratemporal fossa. Treatment of temporal fossa abscess consists of both parenteral antibiotherapy and abscess drainage. Penicillin, cephalosporin, macrolides are the main treatment options, but the culture results can change the treatment plan. Because of the presence of Enterococcus faecalis in 
culture of our case, piperacillin was changed to tasobactam sodium and antibiotherapy regimen was organized due to culture result. Because of cosmetic advantages, abscess drainage can be done with a small incision from the scalp in the postauricular area.

\section{REFERENCES}

1. Boscolo-Rizzo P, Marchiori C, Montolli F, et al. Deep neck infec $\neg$ tions: a constant challenge. ORL J Otorhinolaryngol Relat Spec 2006; 68: 259-65.

2. Stewart PS, Costerton JW. Antibiotic resistance of bacteria in bio $\neg$ films. Lancet 2001; 358: 135.

3. De Oliveira Neto PJ, De Souza Maliska MC, Sawazaki R, et al. Temporal abscess after third molar extraction in the mandible. Oral Maxillofac Surg 2012; 16: 107-10.

4. Lypka M, Hammoudeh J. Dentoalveolar infections. Oral Maxillofac Surg Clin North Am 2011; 23: 415- 24.

5. Diacono MS, Wass AR. Infratemporal and temporal fossa abscess complicating dental extraction. J Accid Emerg Med 1998; 15: 5961.

6. Ward BB. Temporalis system in maxillary reconstruction: temporalis muscle and temporoparietal galea flaps. Atlas Oral Maxillofac Surg Clin N Am 2007; 15: 33-42.

7. Obayashi N, Ariji J, Goto M, et al. Spread of odontogenic infection originating in the maxillary teeth: computerized tomographic assesment. Oral Surg Oral Med Oral Patholo Oral Radiol Endod 2004; 98: 223-31.

8. Morrison A, Brady J. Temporal space abscess secondary to mandibular dental extraction. Oral Health 2009; 99: 17.

9. Flynn T, Shanti R, Levi M, et al. Severe odontogenicinfections, part I: prospective report. J Oral Maxillofac Surg 2006; 64: 1093103. 